\title{
CHARACTER BUILDING DALAM LITERATUR ISLAM KONTEMPORER
}

\author{
DIAN FAUZI ASTUTI
}

\begin{abstract}
Character building is one of the efforts of the Indonesian people to restore noble values that have been distorted. The formation of character (character building) in Islam is really an effort to give birth to a man of knowledge, character, civilized and noble as practiced by the Messenger of Allah. (Madrasah Nabawiyah) which can be used as a reference model for building character education. In contemporary Islamic literature, character building is an effort to develop all aspects of humanity in the physical, emotional, spiritual and intellectual dimensions to produce individuals who have the character of faith, responsibility, care, honesty, courage and become citizens who are well. The model of instilling character values through teaching, habituation, modeling, motivating, and enforcing rules that are implemented consistently and continuously in daily life at home, school, and in the community will form superior individuals as khalifah fi al-Ardli.
\end{abstract}

Keywords: Character building, khalifah fi al-ardli

\section{Pendahuluan}

Dewasa ini muncul berbagai keresahan di kalangan masyarakat terkait perilaku manusia khususnya di negara Indonesia yang sudah banyak menyimpang dari nilainilai luhur agama, budaya dan falsafah bangsa. Bahkan sebagian di antara mereka berani menjustifikasi bahwa kerusakan moral yang terjadi saat ini sudah tergolong kategori rusak berat/parah. Rusaknya moral ini ditandai dengan maraknya praktik korupsi di kalangan elit politik dan pemerintahan. Sementara di tingkat bawah (rakyat) hancurnya moral ini ditunjukkan dengan berbagai tindak kriminal yang merajalela di kalangan masyarakat seperti perampokan, pemerkosaan, penipuan dan pembunuhan. Bahkan kehancuran moral juga terjadi di kalangan pelajar dan remaja yang ditandai dengan maraknya seks bebas, penyalahgunaan narkoba, tawuran antar pelajar, dan lain-lain. Berbagai kerusakan moral tersebut mengindikasikan telah hilangnya nilai-nilai luhur yang melekat pada bangsa Indonesia seperti nillai kejujuran, kesopanan, rasa malu, tanggung jawab, kepedulian sosial dan sebagainya.

Kondisi seperti ini menjadi sangat memprihatinkan jikalau terus dibiarkan berkepanjangan tanpa adanya pemecahan. Hal ini menjadi tanggung jawab kita bersama sebagai bagian dari bangsa Indonesia yang harus berusaha mengembalikan nilai-nilai luhur tersebut menjadi karakter bangsa yang dapat kita banggakan di hadapan negara-negara lain. Adapun salah satu upaya untuk memperbaikinya yaitu dengan meninjau kembali sistem pendidikan nasional bangsa Indonesia dengan menitikberatkan pada pembangunan karakter (character building). 
Pembangunan karakter (character building) selalu dikaitkan dengan proses pendidikan secara formal yang mana proses pendidikan di sini bukan hanya sekedar mentransfer ilmu pengetahuan dari pendidik kepada peserta didiknya. Namun lebih luas dari itu, proses pendidikan juga harus disertai dengan upaya memberikan keteladanan dari seorang pendidik dalam upaya pembentukan karakter peserta didik. Sebagaimana ungkapan William Kilpatrick \& Why Jhonny dalam Lickona (2013) menyatakan bahwa hal paling mendasar yang dihadapi oleh sekolah yaitu hal yang berkenaan dengan pendidikan moral. Adapun masalah-masalah lain yang muncul kemudian, sebenarnya berdasar pada pendidikan moral yang disampaikan. Bahkan perkembangan ilmu pengetahuan pun bergantung pada hasil dari pendidikan karakter. Ungkapan ini menunjukkan bahwa betapa penting pendidikan karakter dalam sebuah proses pendidikan.

Mulyasa (2014) dalam hal ini mengungkapkan bahwa pendidikan karakter harus berkelanjutan dan tak pernah berakhir (never ending process) sebagai bagian terpadu untuk menyiapkan generasi bangsa yang disesuaikan dengan sosok manusia masa depan dan berakar pada filosofi dan nilai kultural religius bangsa Indonesia. Pendidikan karakter harus menumbuhkembangkan filosofi dan pengamalan atas keseluruhan karakter bangsa ini secara utuh dan menyeluruh (kaffah). Menurutnya, karakter bangsa mengandung perekat budaya dan kultural yang harus terwujud dalam kesadaran kultural (cultural awareness) dan kecerdasan kultural (cultural intelligence) setiap warga negara.

Dalam perspektif Islam, pendidikan karakter merupakan upaya untuk mengembangkan keseluruhan aspek kemanusiaan manusia dalam dimensi fisik jasmani, emosi, spiritual dan intelektual untuk menghasilkan pribadi yang memiliki karakter beriman, bertanggung jawab, peduli, jujur, berani dan menjadi warga negara yang baik. Model penanaman nilai karakter melalui pengajaran, pembiasaan, peneladanan, pemotivasian, dan penegakan aturan yang diimplementasikan secara konsisten dan berkesinambungan dalam keseharian di rumah, sekolah, maupun di masyarakat akan membentuk individu berkarakter unggul sebagai khalifah fi al-Ardli (Hasanah: 2014).

Pembangunan karakter (character building) dalam Islam benar-benar merupakan upaya untuk melahirkan seorang yang berilmu, berkarakter, beradab dan berakhlak mulia sebagaimana yang dilakukan oleh Rasulullah saw. (madrasah nabawiyah) yang bisa dijadikan sebagai model rujukan bangunan pendidikan karakter. Pendidikan Rasulullah saw. tidak hanya membentuk akal yang cerdas, tetapi juga membentuk kepribadian yang cemerlang, kepribadian yang mengasah kepekaan jiwa untuk bisa menjadi pribadi yang memberikan manfaat bagi sekitarnya, bukan pribadi yang hanya sekedar cerdas secara intelektual saja, namun tidak peka terhadap persoalan-persoalan sosial yang ada di masyarakat.

Dalam hal ini, Syafri (2014) mengatakan bahwa pendidikan dalam Islam menyeimbangkan antara akal dan hati, antara kecerdasan intelektual dan kecerdasan emosional. Sehingga peserta didik benar-benar menjadi ulil albab, yaitu orang yang mampu mendayagunakan akalnya untuk kepentingan pengabdian kepada Allah swt. dan kiprah di tengah masyarakat. Pendidikan yang menyentuh akal dan hati, juga 
melahirkan sosok ulama (orang-orang yang berilmu) yang hanya takut kepada Allah swt.

Penelitian ini menggunakan metode penelitian kualitatif. Penelitian kualitatif menekankan sifat realita yang terbangun secara sosial, hubungan erat antara peneliti dengan subjek yang diteliti, dan tekanan situasi yang membentuk penyelidikan. Pendekatan yang digunakan adalah deskriptif, yaitu pemaparan data atas uraian dan penafsiran terhadap pembingkaian berita hasil konstruksi suatu realitas. Model analisis yang digunakan dalam penelitian ini adalah analisis framing model dari Robert Entman. Framing merupakan proses memilih beberapa elemen dalam melihat realitas dan mengumpulkan narasi yang menunjukkan hubungan di antara mereka untuk mendukung interpretasi. Framing menunjukkan empat fungsi yaitu problem definition, causal analysis, moral judgment, and remedy promotion (Amri: 2018).

Berangkat dari dasar pemikiran di atas, maka dalam artikel ini penulis akan mengupas tentang bagaimana pembangunan karakter (character building) dalam literatur Islam kontemporer.

\section{Metode}

Kajian ini menggunakan metode penelusuran literatur. Kajian yang berbasis teks ini berupaya mengungkap ide tentang character building dalam literatur pendidikan Islam kontemporer.

\section{Pembahasan}

Dengan menjadikan karakter sebagai substansi ajaran agamanya, Islam jelas merupakan agama yang sangat mengedepankan karakter, bahkan karakter itu sendiri dijadikan sebagai dasar sistem pendidikan dalam Islam. Pendidikan karakter merupakan usaha mempengaruhi jiwa peserta didik untuk menanamkan akhlak sehingga terbentuklah manusia yang berkepribadian dan berbudi luhur sesuai dengan ajaran Islam. Dengan kata lain pendidikan merupakan proses pembentukan karakter.

Karakter dalam pandangan Islam sama dengan akhlak yang memiliki arti sesuatu yang menjadi ciri khas seseorang. Akhlak merupakan hal yang sangat penting, karena selain akal dan pikiran akhlaklah yang membedakan manusia dengan binatang. Jika seseorang berkepribadian baik maka ia berkarakter baik pula. Nilainilai dalam akhlak juga menjadi pedoman bagi nilai-nilai pendidikan karakter dalam Islam. Spiritualitas dan nilai-nilai agama tidak dapat dipisahkan dari pendidikan karakter. Moral dan nilai-nilai spiritual sangat fundamental dalam membangun kesejahteraan organisasi sosial manapun. Tanpa keduanya, maka elemen vital yang mengikat kehidupan masyarakat dapat dipastikan lenyap (Sholihin: 2019).

Islam menggunakan istilah "akhlak" untuk mendeskripsikan karakter. Karakter atau akhlak adalah kondisi stabil jiwa yang menyebabkannya melakukan perbuatan secara spontan dan merasa ringan, tanpa perlu dipikirkan atau ditimbang-timbang terlebih dahulu. Apabila karakter/akhlak tersebut sesuai dengan nilai-nilai Islam, 
maka ia disebut karakter Islami atau akhlak mulia (akhlakul karimah). Akhlak mulia merupakan tuntutan atas keimanan untuk menggapai keridhoan Allah swt. Pendidikan akhlak mulia atau pendidikan karakter Islami adalah upaya untuk membina jiwa agar memiliki kecenderungan untuk secara otomatis berperilaku sesuai dengan tuntunan Islam dalam setiap aspek kehidupan (Pawitasari, Mujahidin \& Nanang: 2015)

Selain itu, karakter juga mempunyai kesamaan dengan hal yang menyangkut kepribadian. Dalam kepribadian ada tiga konsep yang tidak dapat dipisahkan antara satu dengan yang lainnya mencakup: ilmu (pengetahuan), sikap, dan perilaku. Akhlak atau karakter sering diajarkan melalui metode internalisasi, dengan berbagai teknik pendidikan di antaranya dengan peneladanan, pembiasaan, penegakan peraturan dan pemotivasian. Berdasarkan sejarah, Socrates seorang tokoh Yunani menyatakan bahwa tujuan paling mendasar dari pendidikan adalah untuk membuat seseorang menjadi good and smart. Muhammad sebagai nabi terakhir juga telah mencontohkan kepribadian yang baik untuk menjadikan karakter lebih sempurna dan bahkan misi utamanya dalam mendidik manusia yaitu untuk memyempurnakan akhlak dan mengupayakan pembentukan karakter yang baik (good character) (Ubabuddin: 2018).

Senada dengan hal di atas, Mudlofir (2013) mengungkapkan bahwa secara kejiwaan dan sosial budaya, pembentukan karakter dalam diri seseorang merupakan fungsi dari seluruh potensi individu (kognitif, afektif, dan psikomotorik) dalam konteks interaksi sosiokultural (dalam keluarga, satuan pendidikan, dan masyarakat) dan berlangsung sepanjang hayat. Konfigurasi karakter dapat dikelompokkan dalam olah hati (spiritual and emotional development), olah pikir (intellectual development), olah raga dan kinestetik (physical and kinestetic development), serta olah rasa dan karsa (affective, attitude and social development). Keempat proses psikososial tersebut secara terpadu saling berkaitan dan saling melengkapi, yang pada akhirnya bermuara pada pembentukan karakter yang akan menjadi perwujudan dari nilai-nilai luhur.

Dari berbagai ungkapan di atas, dapat digambarkan bahwa pada dasarnya proses pendidikan bukan sekedar meninggikan dimensi kognitif dan psikomotorik yang dimiliki peserta didik. Namun, ada dimensi lain yang juga perlu mendapat perhatian lebih, yaitu dimensi afektif. Disadari atau tidak, dibandingkan dengan dua dimensi lainnya, dimensi afektif kerap terabaikan dengan alasan karena kesulitan untuk mengukur dimensi tersebut. Berdasarkan fenomena tersebut, maka dimensi afektif ini kerap kali terabaikan.

Sebagaimana telah dijelaskan di atas bahwa pembentukan karakter dalam konteks interaksi sosiokultural dapat terbagi ke dalam 3 aspek yaitu keluarga, madrasah/satuan pendidikan dan masyarakat. Senada dengan ini, Sumantri (Ainissyifa: 2014) menyatakan bahwa pembentukan watak atau karakter tentunya harus dimulai dari pribadi/diri sendiri, dalam keluarga (sebagai sel inti bangsa) terutama orang tua sebagai pendidiknya. Pembentukan karakter merupakan "mega proyek" yang sungguh tidak mudah, membutuhkan usaha, dan energi yang tidak sedikit. Dibutuhkan komitmen, ketekunan, keuleten, proses, metode, waktu, dan yang terpenting adalah keteladanan. Masalah keteladanan ini menjadi barang langka pada 
masa kini dan tentu sangat dibutuhkan dalam sebuah bangsa yang sedang mengalami krisis kepercayaan multidimensional.

\section{Pembentukan Karakter dalam Keluarga}

Idrus (2012) menyebutkan tentang hasil penelitian yang dilakukan Erikson (1963), bahwa tampaknya lingkungan di sekitar diri setiap individu penting baginya untuk pewarisan budaya dan pembentukan karakter. Dalam artian bahwa identitas diri anak sebagai wujud pembentukan karakter anak dan perkembangannya akan dipengaruhi oleh lingkungan sekitarnya. Sedangkan lingkungan sekitar terdekat bagi anak adalah keluarganya. Pembentukan identitas salah satunya dipengaruhi hubungan orang tua dan anak. Hal ini mengisyaratkan bahwa interaksi orang tua dan anak yang diwujudkan dalam pola-pola pengasuhan akan mempengaruhi kemampuan anak untuk menyelesaikan konflik yang dialami pada tahap perkembangan psikososial tertentu. Betapa pentingnya pola asuh orang tua bagi pembentukan karakter anak, dan perkembangan anak dipengaruhi oleh pengalaman pengasuhan anak yang kemudian akan mempengaruhi kehidupan anak kelak di masa yang akan datang. Dengan begitu, salah satu institusi penting dalam pembentukan karakter adalah keluarga.

Adapun model pengasuhan yang seperti apa yang dapat membentuk karakter anak sebagaimana yang diharapkan oleh institusi madrasah, masyarakat, bangsa dan negara bahkan agama?. Jika kita berbicara tentang pola asuh, setidaknya perlu dipahami apa sebenarnya yang dimaksud dengan pola asuh itu sendiri. Dalam tulisannya Kohn (Idrus: 2012 ) memaknai gaya pengasuhan sebagai sikap orang tua dalam berhubungan dengan anaknya. Dalam interaksi orang tua dengan anak tersebut juga muncul bagaimana cara orangtua memberikan perhatian, adanya rambu-rambu aturan normatif, disiplin, harapan-harapan orang tua, tanggapan orang tua terhadap keinginan anak, hadiah (reward) ataupun hukuman (punishment) yang diberikan, yang semuanya dimaksudkan untuk memberikan bimbingan kepada anak agar dapat berkembang sesuai dengan yang seharusnya.

Anisah (2011) mengungkapkan bahwa pola asuh adalah suatu model perlakuan atau tindakan orang tua dalam membina dan membimbing serta memelihara anak agar dapat berdiri sendiri. Lebih dari itu pola asuh ini akan membentuk watak dan karakter anak di masa dewasanya. Perlakuan orang tua kepada anak-anaknya sejak masa kecil akan berdampak pada perkembangan sosial moral di masa dewasanya. Perkembangan sosial moral inilah yang akan membentuk watak, sifat dan sikap anak kelak meskipun ada beberapa faktor lain yang berpengaruh dalam pembentukan sikap anak yang tercermin dalam karakter yang dimilikinya. Secara teoritis, pola asuh yang dilakukan orang tua memiliki 3 jenis yang terdiri dari pola asuh gaya otoriter (Authoritarian style), gaya permisif (Permisive style) dan gaya otoritatif/gaya memerintah (Authoritative style).

Pola asuh gaya otoriter (Authoritarian style) adalah tipe pola asuh dimana orang tua terlalu banyak menuntut dan sangat kurang merespon dan menanggapi keinginan anak. Pengasuhan otoriter ini merupakan suatu gaya yang membatasi, menghukum dan menuntut anak untuk mengikuti perintah-perintah orang tua dan 
tidak memberi peluang kepada anak untuk berbicara. Pola asuh otoriter ini berpengaruh negatif terhadap kemampuan sosial dan kognitif anak. Sehingga efeknya anak tidak mampu bergaul dengan teman sebaya, selalu menyendiri, merasa cemas dan gelisah serta khawatir ketika bergaul dengan teman sebaya dan lebih dikhawatirkan lagi akan memiliki hati nurani yang rendah. Pola asuh otoriter ini berdampak panjang terhadap kelangsungan perkembangan psikis anak dalam bersosialisasi, memiliki hati nurani yang rendah akan berakibat pada kepribadian anak ketika dewasa kelak.

Pola asuh permisif (Permisive style) yaitu suatu gaya dimana orang tua sangat tidak terlibat dalam kehidupan anak. Dalam pola asuh ini akan lebih ditemukan adanya kehangatan dibanding dengan pola asuh otoriter. Orang tua dengan pola asuh permisif juga bersikap dingin, tidak banyak terlibat dalam kegiatan anak dan lebih bersikap acuh.

Pola asuh otoritatif (Authoritative style) yaitu pola asuh yang mendorong anak agar mandiri tetapi masih menetapkan batasan-batasan dan pengendalian atas tindakan mereka. Pola asuh ini memperlihatkan kehangatan atau kasih sayang dan adanya musyawarah. Pola asuh otoritatif ini disinyalir sebagai salah satu pola asuh yang terbaik karena merupakan kombinasi antara tuntutan (demandingness) dan membolehkan atau mengijinkan (responsiveness) serta memiliki pengaruh yang baik terhadap perkembangan anak. Dengan demikian pola asuh otoritatif ini mendorong anak untuk memiliki kemampuan yang lebih baik daripada pola asuh otoriter ataupun permisif. Anak-anak dari orang tua yang memiliki pola asuh otoritatif sangat memelihara tanggung jawab sosial dan kebebasan ketika masih kanak-kanak, dan sesudah menginjak usia 8-9 tahun baik anak laki-laki maupun anak perempuan sudah memiliki kecakapan emosional artinya kognitif sosialnya sudah dimiliki (berkembang ke arah positif).

Ketiga pola asuh tersebut memiliki pengaruh besar terhadap pembentukan kepribadian anak dan juga sangat menentukan watak, sikap dan perilaku anak. Di sinilah pentingnya pendidikan keluarga yang dalam pendidikan keluarga ini seyogyanya dibutuhkan aturan yang benar dan memiliki kekuatan sehingga bisa mengikat para anggota keluarga untuk mematuhi dan melaksanakannya.

Islam sendiri sudah jelas memiliki aturan yang benar tentang pembinaan/pendidikan keluarga, mulai dari membangun keluarga, interaksi antara ayah dan ibu, bagaimana pola asuh dijalankan dengan melihat dua karakter yang berbeda yaitu orang tua dan anak. Al- Qur`an dan Hadits yang dalam hal ini sebagai sumber pokok ajaran Islam sudah menggariskan semua aturan untuk berbagai interaksi dalam sebuah keluarga sebagai salah satu acuan pembinaan akhlak mulia.

Dalam perspektif Islam, keluarga sebagai "school of love" dapat disebut sebagai "madrasah mawaddah wa rahmah", tempat belajar yang penuh cinta sejati dan kasih sayang. Islam memberikan perhatian yang sangat besar kepada pembinaan keluarga (usrah). Keluarga merupakan basis dari bangsa (ummah); dan karena itu keadaan keluarga sangat menentukan keadaan ummah itu sendiri. Bangsa terbaik (khairu ummah) yang merupakan bangsa yang satu (ummah wahidah) dan bangsa yang moderat (ummah wasath), sebagaimana dicita-citakan Islam hanya dapat terbentuk 
melalui keluarga yang dibangun dan dikembangkan atas dasar mawaddah warahmah (Subianto: 2013).

\section{Pendidikan Karakter dalam Satuan Pendidikan}

Pendidikan karakter dalam hal ini adalah suatu sistem penanaman nilai-nilai karakter kepada warga sekolah yang meliputi komponen pengetahuan, kesadaran atau kemauan, dan tindakan untuk nilai-nilai tersebut. Pendidikan karakter pada hakekatnya ingin membentuk individu menjadi seorang pribadi bermoral yang dapat menghayati kebebasan dan tanggung jawabnya, dalam relasinya dengan orang lain dan dunianya dalam komunitas pendidikan. Dengan demikian pendidikan karakter senantiasa mengarahkan diri pada pembentukan individu bermoral, cakap mengambil keputusan yang tampil dalam perilakunya, sekaligus mampu berperan aktif dalam membangun kehidupan bersama. Adapun nilai-nilai pendidikan karakter bersumber dari agama, pancasila, budaya, dan tujuan pendidikan nasional.

Pendidikan karakter bukanlah berupa materi yang hanya bisa dicatat dan dihafalkan serta tidak dapat dievaluasi dalam jangka waktu yang pendek, tetapi pendidikan karakter merupakan sebuah pembelajaran yang teraplikasi dalam semua kegiatan peserta didik baik di sekolah, lingkungan masyarakat dan lingkungan di rumah melalui proses pembiasaan, keteladanan, dan dilakukan secara berkesinambungan. Oleh karena itu keberhasilan pendidikan karakter ini menjadi tanggung jawab bersama antara sekolah, masyarakat dan orang tua. Evaluasi dari keberhasilan pendidikan karakter ini tentunya tidak dapat dinilai dengan tes formatif atau sumatif yang dinyatakan dalam skor. Tetapi tolak ukur dari keberhasilan pendidikan karakter adalah terbentuknya peserta didik yang berkarakter; berakhlak, berbudaya, santun, religius, kreatif, inovatif yang teraplikasi dalam kehidupan di sepanjang hayatnya. Oleh karena itu, tentu tidak ada alat evaluasi yang tepat dan serta merta dapat menunjukkan keberhasilan pendidikan karakter.

Konfigurasi karakter sebagai sebuah totalitas proses psikologis dan sosialkultural dapat dikelompokan dalam: Olah Hati (Spiritual and emotional development), Olah Pikir (intellectual development), Olah Raga dan Kinestetik (Physical and kinestetic development), dan Olah Rasa dan Karsa (Affective and Creativity development). Keempat proses psikososial (olah hati, olah pikir, olah raga, dan olah rasa dan karsa) tersebut secara holistik dan koheren memiliki keterkaitan dan saling melengkapi, yang bermuara pada pembentukan karakter yang menjadi perwujudan dari nilai-nilai luhur. Pendidikan karakter ini menjadi salah satu akses yang tepat dalam melaksanakan character building bagi generasi muda; generasi yang berilmu pengetahuan tinggi dengan dibekali iman dan bertakwa kepada Tuhan Yang Maha Esa, berakhlak mulia, cakap, kreatif, mandiri, dan menjadi warga negara yang demokratis serta bertanggung jawab (Ainiyah: 2013).

Pendidikan karakter pada dasarnya mencakup pengembangan substansi, proses, dan suasana atau lingkungan yang menggugah, mendorong, dan memudahkan seseorang untuk mengembangkan kebiasaan baik dalam kehidupan sehari-hari. Kebiasaan ini timbul dan berkembang dengan didasari oleh kesadaran, keyakinan, kepekaan, dan sikap orang yang bersangkutan. Pendidikan karakter dalam Satuan 
Pendidikan diniscayakan untuk menekankan pada keteladanan, penciptaan lingkungan, dan pembiasaan melalui berbagai tugas keilmuan dan kegiatan kondusif. Dengan demikian, apa yang dilihat, didengar, dirasakan, dan dikerjakan oleh peserta didik dapat membentuk karakter mereka. Selain menjadikan keteladanan dan pembiasaan sebagai metode pendidikan utama, penciptaan iklim dan budaya, serta lingkungan yang kondusif juga sangat penting, dan turut membentuk karakter peserta didik.

Ramdhani (2014) dalam jurnalnya yang dikutip dari Mulyasa (2013) menyatakan bahwa kunci sukses pendidikan karakter pada Satuan Pendidikan adalah: a. Semua pendidik harus memahami hakikat pendidikan karakter; b. Sosialisasikan pendidikan karakter dengan tepat; c. Ciptakan lingkungan yang kondusif; d. Dukung dengan fasilitas dan sumber belajar yang memadai; e. Tumbuhkan disiplin peserta didik; f. Pilih pimpinan yang amanah; g. Wujudkan guru yang dapat digugu dan ditiru; serta h. Libatkan seluruh warga sekolah.

Syafe'i (2017) mengungkapkan bahwa salah satu institusi pendidikan yang disinyalir telah lama menerapkan pendidikan karakter adalah pondok pesantren. Pondok Pesantren sebagai salah satu sub-sistem Pendidikan Nasional yang indigenous Indonesia, bahkan dipandang oleh banyak kalangan mempunyai keunggulan dan karakteristik khusus dalam mengaplikasikan pendidikan karakter bagi anak didiknya (santri). Pandangan demikian tampaknya berasal dari kenyataan bahwa: pesantren lebih mudah membentuk karakter santrinya karena institusi pendidikan ini menggunakan sistem asrama yang memungkinkannya untuk menerapkan nilai-nilai dan pandangan dunia yang dianutnya dalam kehidupan keseharian santri. Telah banyak penelitian yang dilakukan berkaitan dengan pondok pesantren dan pendidikan karakter, diantaranya (Aulia \& Samino, 2015; Faiqoh \& Mahfudh, 2015; Kurniawan, 2016; Makmun, 2014; Nuryana, 2013; Rodliyah, 2014; Subekti, 2015; Sulaiman, 2013; Ubaidillah, 2016; Zuhriy, 2011).

\section{Pendidikan Karakter dalam Masyarakat}

Karakter merupakan nilai-nilai perilaku manusia yang berhubungan dengan Tuhan Yang Maha Esa, sesama manusia, lingkungan, diri sendiri, dan kebangsaan yang terwujud di dalam adat istiadat, budaya, tata krama, hukum, pemikiran, sikap, perasaan, perkataan, dan perbuatan berdasarkan norma-norma agama. Lickona mengatakan bahwa pendidikan karakter ialah suatu upaya yang disengaja untuk membantu seseorang sehingga ia dapat melakukan nilai-nilai etika, memperhatikan dan memahaminya. Pendidikan karakter membutuhkan metode khusus yang tepat agar tujuan pendidikan bisa tercapai, di antaranya metode pembelajaran yang sudah sesuai ialah metode pujian dan hukuman, metode pembiasaan, dan metode keteladanan. Karakter mutlak dibutuhkan bukan hanya di lingkungan sekolah saja, tetapi di lingkungan rumah dan juga di lingkungan sosial/masyarakat. Bahkan sekarang ini pesertanya bukan lagi anak usia dini hingga remaja, tetapi juga meliputi usia dewasa. Di zaman milenial ini kita akan berhadapan dengan berbagai persaingan termasuk dengan rekan-rekan di berbagai belahan negara di dunia. Tuntutan zaman dari berbagai kualitas SDM pada tahun 2021 mendatang tentunya akan membutuhkan karakter yang baik. Karena dalam hal ini karakter merupakan salah 
satu kunci dari keberhasilan individu. Berdasarkan penelitian bahwa 80\% keberhasilan untuk seseorang di masyarakat ditentukan oleh (EQ). Pendidikan karakter saat ini telah menjadi pusat perhatian di berbagai belahan dunia dalam rangka menyiapkan generasi yang baik, tidak hanya untuk kepentingan individu warga negaranya saja tetapi untuk keseluruhan warga masyarakat (Subianto: 2013).

Mengutip dari Koesoema (2010), Subianto juga memberikan formula bahwa jika pendidikan karakter ingin efektif dan utuh, maka harus menyertakan tiga basis desain dalam programnya. Di antaranya yaitu:

1) Desain pendidikan karakter berbasis kelas. Desain ini berbasis pada relasi guru sebagai pendidik dan siswa sebagai pembelajar di dalam kelas. Konteks pendidikan karakter adalah proses relasional komunitas kelas dalam konteks pembelajaran. Relasi guru-pembelajar bukan monolog, melainkan dialog dengan banyak arah sebab komunitas kelas terdiri dari guru dan siswa yang sama-sama berinteraksi dengan materi. Memberikan pemahaman dan pengertian akan keutamaan yang benar terjadi dalam konteks pengajaran ini, termasuk di dalamnya pula adalah ranah noninstruksional, seperti manajemen kelas, konsensus kelas, dan lain-lain, yang membantu terciptanya suasana belajar yang nyaman.

2) Desain pendidikan karakter berbasis kultur sekolah. Desain ini mencoba membangun kultur sekolah yang mampu membentuk karakter anak didik dengan bantuan pranata sosial sekolah agar nilai tertentu terbentuk dan terbatinkan dalam diri siswa. Untuk menanamkan nilai kejujuran tidak cukup hanya dengan memberikan pesan-pesan moral kepada anak didik. Pesan moral ini mesti diperkuat dengan penciptaan kultur kejujuran melalui pembuatan tata peraturan sekolah yang tegas dan konsisten terhadap setiap perilaku ketidakjujuran.

3) Desain pendidikan karakter berbasis komunitas. Dalam mendidik, komunitas sekolah tidak berjuang sendirian. Masyarakat di luar lembaga pendidikan, seperti keluarga, masyarakat umum, dan negara, juga memiliki tanggung jawab moral untuk mengintegrasikan pembentukan karakter dalam konteks kehidupan mereka. Ketika lembaga negara lemah dalam penegakan hukum, ketika mereka yang bersalah tidak pernah mendapatkan sanksi yang setimpal, negara telah mendidik masyarakatnya untuk menjadi manusia yang tidak menghargai makna tatanan sosial bersama.

Di kalangan pemerhati pendidikan, pendidikan holistik dianggap merupakan salah satu solusi bagi masalah-masalah yang dihadapi bangsa. Dekadensi moral yang menghinggapi generasi muda berdampak buruk pada moral individu di berbagai aspek kehidupan, dan melalui sistem pendidikan holistik diharapkan dapat menghasilkan output yang unggul dalam berbagai aspek terlebih dalam hal moral. Tujuan pendidikan holistik, adalah pendidikan menghasilkan manusia yang terintegrasi, yang mampu menyatu dengan kehidupan sebagai satu kesatuan.

Dalam agama Islam, karakter adalah inti dari pendidikan Islam yang semula dikenal dengan pendidikan akhlak, yaitu pendidikan yang mengantarkan pesrta didik dapat bersikap dan berperilaku sesuai dengan nilai-nilai karakter yang Islami. 
Raharjo dikutip dari Muali (2017) memaknai pendidikan karakter sebagai suatu proses pendidikan secara holistik yang menghubungkan dimensi moral dengan ranah sosial dalam kehidupan peserta didik sebagai fondasi bagi terbentuknya generasi yang berkualitas yang mampu hidup mandiri dan memiliki prinsip suatu kebenaran yang dapat dipertanggung jawabkan. Dengan tujuan terbentuknya al-Insan al-Kamil yang menitikberatkan pada konsep hubungan manusia dengan sesama, manusia dengan lingkungan dan manusia dengan Tuhannya. Konsep pendidikan karakter akan semakin mudah diaplikasikan dalam menumbuh kembangkan potensi peserta didik dengan pendekatan pendidikan holistik.

Domain kognitif berkenaan dengan hasil belajar intelektual yang terdiri dari enam aspek, yakni pengetahuan atau ingatan, pemahaman, aplikasi, analisis, sintesis, dan evaluasi. Kedua aspek pertama disebut kognitif tingkat rendah dan keempat aspek berikutnya termasuk kognitif tingkat tinggi. Domain afektif berkenaan dengan sikap yang terdiri dari lima aspek yakni penerimaan, jawaban atau reaksi, penilaian, organisasi dan internalisasi. Domain psikomotorik berkenaan dengan hasil belajar keterampilan dan kemampuan bertindak. Ada enam aspek ranah psikomotorik yakni (a) gerakan refleks, (b) keterampilan gerakan dasar, (c) kemampuan perseptual, (d) keharmonisan atau ketepatan, (e) gerakan keterampilan kompleks, dan (f) gerakan ekspresif dan interpretatif.

Sedangkan domain iman amat diperlukan, karena ajaran Islam tidak hanya menyangkut hal-hal rasional, tetapi juga menyangkut hal-hal yang supra rasional, dimana akal manusia tidak akan mampu menangkapnya, kecuali didasari dengan iman, yang bersumber dari wahyu yaitu al-Qur’an dan al-Hadist. Domain iman merupakan titik sentral yang hendak menentukan sikap dan nilai hidup peserta didik, dan dengannya pula menentukan nilai yang dimiliki dan amal yang dilakukan. Dengan kata lain, keimanan atau kesadaran tauhid menjadi rambu-rambu bagi manusia dalam melakukan penelusuran terhadap berbagai fenomena alam dan sosial, baik yang bersifat material maupun immaterial. Keimanan akan membuat manusia dapat menjalankan tugasnya sebagai wakil Allah di muka bumi (khalifah). Pendekatan holistik menghendaki pendekatan yang utuh, tidak parsial, komprehensif tidak sepotong-potong, dan saling berhubungan. Manusia terdiri dari empat elemen yakni intelektual, emosi, inderawi-fisik, dan spiritual. Tiap-tiap elemen ini memiliki sisi-sisi yang harus dikembangkan. Daya emosi adalah perpaduan keseimbangan kesadaran diri dan kesadaran sosial yang bertumpu pada kecerdasan spiritual. Puncak dari daya emosi adalah spiritualitas. Daya pikir adalah kemampuan optimum dari berpikir linear, asosiatif dan integral. Puncak dari berpikir intelektual adalah berpikir integral atau holistik. Daya fisik atau kematangan fisik dapat optimum jika memperhatikan asupan makanan yang bergizi, thayyib, dan halal. Puncak dari kebaikan perkembangan fisik adalah kehalalan (Muali: 2017).

Islam secara keseluruhan telah memiliki suatu cara dalam menumbuh kembangkan manusia mencapai titik optimumnya, yang dalam proses optimalisasi itu, Islam meletakkan fondasi kuat dengan keimanan untuk menjaga ilmu. Perintah belajar, seiring dengan proses pendidikan dalam konteks Islam tidak lain adalah proses optimalisasi diri manusia dalam menemukan keyakinan tentang Allah swt. Oleh sebab itu pendidikan dalam Islam tidak bebas nilai. Pendidikan Islam bersifat menyeluruh, berkesinambungan, memiliki pondasi, kerangka, tujuan dan evaluasi 
yang telah jelas kriterianya. Pendidikan Islam berorientasi pada individu manusia, yang dengan demikian maka manusia tidak akan pernah merasa kehilangan eksistensi meskipun dunia berubah sangat cepat, dan berubah tidak sesuai dengan yang dikehendaki. Islam lahir dengan revolusi tauhid, yang mengubah paradigma berpikir tentang yang nyata dan yang ghaib yang lahir dari yang satu yaitu Allah swt. Oleh karena itu, dalam konsep pendidikan holistik dalam pendidikan karakter perspektif Islam, peran tauhid menjadi titik sentral sebagai penyatu semua elemen manusia, dan puncak dari proses pendidikan individu tersebut adalah spiritual. Sehingga dengan konsep pendidikan holistik tersebut akan mampu meningkatkan kapasitas iman, ilmu, dan amal setiap manusia. Konsep pendidikan holistik adalah konsep pendidikan yang unggul dan terdepan dalam memberdayakan manusia seutuhnya. Pendidikan holistik yang dalam membentuk karakter bersifat integrated yang berbasiskan kompetensi dan mengakomodir seluruh kecerdasan manusia. Pendekatannya bersifat aplikatif dan problem solving untuk mengupayakan kemandirian. Selain itu pendekatan lingkungan digunakan pula untuk memberikan siswa kesempatan membaur bersama masyarakat dalam mengimplementasikan ilmunya. Sementara itu, evaluasi dilakukan secara bertahap berkesinambungan baik dalam berbagai bentuk formal tertulis maupun observasi langsung oleh pendidik dalam keseharian Islam, observasi menjadi bagian penting untuk mengukur tingkat keberhasilan murid (Maksudin 2013).

Dalam model pendidikannya ialah dengan memfokuskan pada pembentukan seluruh aspek dimensi manusia, sehingga dapat menjadi manusia yang berkarakter. Model pendidikan ini menerapkan teori-teori sosial, emosi, kognitif, fisik, moral, dan spiritual. Model ini diharapkan dapat memberikan kemampuan bagi siswa agar berkembang menjadi individu yang terintegrasi dengan baik secara spiritual, intelektual, sosial, fisik, dan emosi, yang berpikir kreatif dan mandiri, serta bertanggung jawab. Membentuk manusia secara utuh (holistik) yang berkarakter, yaitu mengembangkan aspek fisik, emosi, sosial, kreativitas, spiritual dan intelektual siswa secara optimal. Selain itu untuk membentuk manusia yang life long learners (pembelajar sejati). Implementasi pendidikan holistik adalah dengan memfokuskan pada pembentukan seluruh aspek dimensi manusia sehingga dapat menjadi manusia yang berkarakter.

\section{Simpulan}

Pembentukan karakter (character Building) dalam konteks interaksi sosiokultural dapat terbagi ke dalam 3 aspek yaitu keluarga, madrasah/satuan pendidikan dan masyarakat. Pembentukan watak atau karakter tentunya harus dimulai dari pribadi/diri sendiri, dalam keluarga (sebagai sel inti bangsa) terutama orang tua sebagai pendidiknya. Pembentukan karakter merupakan "mega proyek" yang sungguh tidak mudah, membutuhkan usaha, dan energi yang tidak sedikit. Dibutuhkan komitmen, ketekunan, keuleten, proses, metode, waktu, dan yang terpenting adalah keteladanan. Masalah keteladanan ini menjadi barang langka pada masa kini dan tentu sangat dibutuhkan dalam sebuah bangsa yang sedang mengalami krisis kepercayaan multidimensional. 
Identitas diri seorang anak sebagai wujud pembentukan karakter dan perkembangannya sangat dipengaruhi oleh lingkungan sekitarnya. Sedangkan lingkungan sekitar terdekat bagi anak adalah keluarganya. Pembentukan identitas salah satunya dipengaruhi hubungan orang tua dan anak. Hal ini mengisyaratkan bahwa interaksi orang tua dan anak yang diwujudkan dalam pola-pola pengasuhan akan mempengaruhi kemampuan anak untuk menyelesaikan konflik yang dialami pada tahap perkembangan psikososial tertentu. Betapa pentingnya pola asuh orang tua bagi pembentukan karakter anak, dan perkembangan anak dipengaruhi oleh pengalaman pengasuhan anak yang kemudian akan mempengaruhi kehidupan anak kelak di masa yang akan datang. Dengan begitu, salah satu institusi penting dalam pembentukan karakter adalah keluarga.

Salah satu institusi pendidikan yang disinyalir telah lama menerapkan pendidikan karakter adalah pondok pesantren. Pondok Pesantren sebagai salah satu sub-sistem Pendidikan Nasional yang indigenous Indonesia, bahkan dipandang oleh banyak kalangan mempunyai keunggulan dan karakteristik khusus dalam mengaplikasikan pendidikan karakter bagi anak didiknya (santri). Pandangan demikian tampaknya berasal dari kenyataan bahwa: pesantren lebih mudah membentuk karakter santrinya karena institusi pendidikan ini menggunakan sistem asrama yang memungkinkannya untuk menerapkan nilai-nilai dan pandangan dunia yang dianutnya dalam kehidupan keseharian santri

Masyarakat di luar lembaga pendidikan, seperti keluarga, masyarakat umum, dan negara, juga memiliki tanggung jawab moral untuk mengintegrasikan pembentukan karakter (character building) dalam konteks kehidupan mereka. Ketika lembaga negara lemah dalam penegakan hukum, ketika mereka yang bersalah tidak pernah mendapatkan sanksi yang setimpal, negara telah mendidik masyarakatnya untuk menjadi manusia yang tidak menghargai makna tatanan sosial bersama.

\section{DAFTAR PUSTAKA}

Ainiyah, Nur. (2013). Pembentukan Karakter Melalui Pendidikan Agama Islam. Jurnal Al-'Ulum, 13 (1), 25-38.

Ali Ramdhani, Muhammad. (2014). Lingkungan Pendidikan dalam Implementasi Pendidikan Karakter. Jurnal Pendidikan Universitas Garut, 08 (1), 28-37.

Amri, Mariani. (2018). Islam dan Pendidikan Karakter Dalam Framing Media Online. Ta'dib; Jurnal Pendidikan Islam, 7 (1). 445-453.

Hasanah, Aan. (2014). Kerangka Konsep Pendidikan Karakter Bangsa Dalam Perspektif Islam. JURNAL PENJAMINAN MUTU, I (1), 186-210.

Idrus, Muhammad. (2012). Pendidikan Karakter Pada Keluarga Jawa. Jurnal Pendidikan Karakter, II (2), 118-130. 
Lickona, Thomas. (2013). Mendidik Untuk Membentuk Karakter: Bagaimana Sekolah Dapat Memberikan Pendidikan tentang Sikap Hormat dan Bertanggung jawab. Jakarta: Bumi Aksara.

Maksudin.( 2013). Pendidikan Karakter Non Dikotomik. Yogyakarta: Pustaka Pelajar.

Muali, Chusnul. (2017). Rasionalitas Konsepsi Budaya Nusantara Dalam Menggagas Pembentukan Karakter Bangsa Multikultural. Jurnal Islam Nusantara, 01 (01). 105-117.

Mudlofir, Ali. (2013). Pendidikan Karakter: Konsep dan Aktualisasinya dalam Sistem Pendidikan Islam. Nadwa Jurnal Pendidikan Islam, 7 (2), 230-244.

Mulyasa. (2014). Manajemen Pendidikan Karakter. Jakarta: Bumi Aksara.

Pawitasari, Erma., Mujahidin, Endin \& Fattah, Nanang. (2015). Pendidikan Karakter Bangsa Dalam Perspektif Islam (Studi Kritis terhadap Konsep Pendidikan Karakter Kementerian Pendidikan \& Kebudayaan). Ta'dibuna, 4(1), 1-20

Sholihin, M. (2019). Pendidikan Karakter Dalam Perspektif Islam. Ta'lim JIAI, 1 (2), 50-64.

Siti Anisah, Ani. (2011). Pola Asuh Orang Tua dan Implikasinya Terhadap Pembentukan Karakter Anak. Jurnal Pendidikan Universitas Garut, 05 (01), 7084.

Subianto, Jito. (2013). Peran Keluarga, Sekolah dan Masyarakat Dalam Pembentukan Karakter Berkualitas. Adukasia: Jurnal Penelitian Pendidikan Islam, 8 (2), 331354.

Syafe'i, Imam. (2017). Pondok Pesantren: Lembaga Pendidikan Pembentukan Karakter. Al-Tadzkiyyah Jurnal Pendidikan Islam, 8 (I), 61-82.

Ubabuddin. (2018). Konsep Pendidikan Karakter Perspektif Islam. Ta'dib Jurnal Pendidikan Islam, 7 (1), 454-460. doi: 10.29313/tjpi.v7i1.3428 
